\title{
Some Problems about the Learning of the English Language in 19th c. Spain: Philological Notes Referring to an Unpublished Collection of Letters
}

\author{
Mar Vilar \\ Universidad de Murcia
}

\begin{abstract}
At Wadham College, Oxford, there are seven letters by Santiago Usoz y Río, a professor of Greek at the University of Santiago de Compostela, addressed to the Hispanist Benjamin B. Wiffen, dated between 9th January 1841 and 25th September 1850. As far as the philological interest of the letters is concerned, nos. I, II, III and IV deal with Santiago Usoz's problems as autodidact to learn the English language. Not only did his linguistic intuitions derive from his command of the classical languages but also the awareness of his own technical limitations - that is, the rudimentary Traditional or Grammatical techniques of his time- will immerse us into Usoz's efforts to achieve - by means of translation-some purely extraphilological aims.
\end{abstract}

\section{Historical framework}

At Wadham College, Oxford, Spanish collection, Wiffen Papers, amongst other papers referring to Spain, there are seven letters by Santiago Usoz y Río addressed to the hispanist Benjamin B. Wiffen, dated between 9th January 1841 and 25th September 1850.

This collection of letters, of which we have prepared a critical edition, ${ }^{1}$ offers us a noteworthy testimony of middle 19th C. Spanish reality and, at the same time, a progressive and anglophile intellectual Spaniard's view -equally interesting- of contemporary England and its influence on Spain. This influence must be understood in terms of the growing concern of the Spanish élites for the English language and the 
practical problems posed for its correct learning, and also the progress detected in certain Spanish intellectual circles as regards the familiarization with British thought, literature, customs and new developments. The letters especially mention the evident disparities between both cultures; and also the far from negligible difficulties that the Spaniard of the period had to immerse himself into the English language with no other help than those rudimentary manuals to which $\mathrm{S}$. Martín-Gamero refers.

Between 1841-1850, the frame for the letters of our study, we witness one of the most trascendental periods. After a bloody civil war of seven years (1833-1839), the so-called 1st Carlist war, the militarily defeated absolutism put an end to any reasonable possibility of returning to the Ancien Régime and consequently gave way to the definitive consolidation of liberalism.

Moreover, the bourgeois revolution was accomplished on a national scale by means of a vast piece of legislative work which, in spite of all its defects (the failure of the sale of Church lands as land reform, for instance) made possible a great attempt at modernization in the country, as well as the consequent renewal of the Industrial Revolution. Unfortunately, many sequels that had survived the past together with other facts curbed the process of the institutional renewal and the socio-economic transformations undertaken. Events such as the systematic subordination of the general interest to the partisan interest, the antiliberal militancy of the Catholic Church (both deprived of its privileges and stripped of its wealth by the middle-class) and the split of the liberal field into two opposing tendencies, moderate and progressive. These tendencies were forced to resort to the Army in order to keep off the defeated absolutism and to escape the devastating effects of their own internal dissensions.

\section{The author and the addressee}

This bustling Spain, full of expectations and under transformation is well represented by Santiago Usoz, born in Arequipa (Perú) around 1812, son of a Spanish official of Navarrese origin who was repatriated with his family in the middle of the vicissitudes which accompanied the independence of that country. Usoz, guided by his elder brother Luis, a reputable Hellenist and Hebraist and famous dissenter, ${ }^{2}$ studied humanities, classical languages and Law at the Universities of Alcalá and Valladolid. Eventually, he became one of the fathers of contemporary Spanish Hellenism, the first Greek professor at the University of Santiago (the period in which the letters are dated) and later on at Salamanca, where he left everlasting memory. In his letters, Usoz, still young, reveals himself not only as an implacable detractor of the fatal stagnation to which a great deal of his compatriots still stuck but also as a champion of reason, justice and progress. His enthusiasm (it should be said, a bit naive) made him see in the England of his time, at that time at the height of its power, the model and image of what Spain should be some day.

As far as the addressee is concerned, we find the Hispanist Benjamin Barron Wiffen, born in 1794 in the small town of Woburn, Bedfordshire, in the bosom of a well-to-do family of German origin. His brother, Jeremiah Wiffen, was a well-known literary critic and translator of Garcilaso de la Vega ${ }^{3}$ and Torquato Tasso ${ }^{4}$ into the English language. For 
more than a quarter of a century, Benjamin developed an exemplary intellectual collaboration with Luis Usoz, who made possible the splendid Colección de Reformistas Antiguos Españoles (Pattinson 1-62, 79-142) where the 19th century heterodox Spaniards' works were published and studied. When Luis died, in 1865 , twenty volumes had been already published in London, Madrid and San Sebastian. They included important titles of outstanding humanists such as Juan and Alfonso de Valdés, Juan Pérez de Pineda, Cipriano de Valera, Francisco de Enzinas, Constantino Ponce de la Fuente, etc. In turn, when Wiffen died, in 1867, leaving a great quantity of unpublished material, the work was finally completed by his friend Edward Boehmer. This German Hispanist published Wiffen's papers in three thick volumes between 1874 and 1904, with the title Biblioteca Wiffeniana. Spanish Reformers of Two Centuries from 1520.

\section{The letters}

They were written in Madrid, except for nos. VI and VII (19th and 25th September 1850), which were written in Santiago de Compostela. All of them are signed. Letter no. I has an English translation by Wiffen, unfinished and inserted between the Spanish lines. Attached to no. VI there is a complete translation into English together with a short note -Southampton 27th July 1850-, in English and with its Spanish translation also by the same British addressee. This one informed the Spanish visitor that Joseph Clarke, Wiffen's friend, would be waiting for him to show him the way to Mount Pleasant, in Aspley, Woburn, where both he and one of his sisters waited for him with eagerness. As mentioned above, this collection of letters was written between 9th January 1841 and 25th September $1850 .^{5}$

Letter no. 1 (Madrid, 9th January 1841) answers another written by Wiffen on 23rd December 1840 . In it he comments on the itinerary followed in his journey from Madrid to Valencia across La Mancha accompanied by Dr. G.W. Alexander "... por esos pueblos miserables de torres altas, estrechas y éticas como la figura de nuestro don Quijote.” In Usoz's opinion, it had been more pleasant to follow the optional route that crossed la Alcarria and Aragon, a route about which both British travellers had thought initially. Finally, the author whose remote Basque-Navarrese origin emerges unconsciously, states that "... no habiendo visto [La] Rioja y las Provincias Vascongadas, puede decirse que está lo mejor por ver." On the other hand, the rest of the long missive refers to the efforts made by Alexander and Wiffen to establish an abolitionist society in Madrid. Despite the fact that it did not succeed for being considered a “... club de hombres pagados por el gobierno inglés más bien que como una sociedad puramente filantrópica”, they kept on struggling against slavery in Cuba, at that time a Spanish possession. That is why Santiago Usoz offered himself either to revise a translation already in existence of the antislavery treatise by Frederic Madden (apparently too literal and therefore offensive for those who supported slavery in Spain), or to translate it again in order to make it accessible to the Hispanic public without damaging their sensitivity.

In letter no. II (Madrid March 1843) two years later, Usoz refers to this point again. "La causa de la emancipación [de los esclavos en las Antillas] -he regrets- adelanta muy 
poco o nada." In his opinion, because of the stern opposition of the Spanish political class to the project, regarded as something damaging both to the island "sacarocracia" and to the Cuban planters in general. He also touches on other matters especially the one which refers to the lack of notes and non-canonical books in George Borrow's edition in Madrid of the version of the Bible by Felipe Scío de San Miguel; ${ }^{6}$ with the consequent rejection on the part of Spanish Catholics. For a change, letter no. III, written in Madrid 18th March 1843, entirely focuses on the practical problems that Usoz, with no other help than the reading of William Cowper's poems, encounters in the learning of the English language, despite the absence of the native speaker who had initiated him in it. And although he states that he completely lacks some knowledge of the English literature, judging by the comparative reflection he makes on the works of Byron and Cowper, not at all mistaken, we may suspect that he did have some idea. Likewise, he has certain linguistic intuitions as he poses the problematic relationship between the phonic side of words and their corresponding meaning.?

In letter no. IV, (Madrid 30th June 1843), we discover how Santiago Usoz, some months later, continues reading Cowper and is already able to observe the quality of his poetry (preromantic spirit, liking for nature, simplicity of expression). Nevertheless, once more, he regrets having a poor command of the English language, in particular his serious limitations regarding pronunciation that make him unable to obtain greater benefit from his reading. He praises The Charity as an outstanding work, ${ }^{8}$ though he rejects the distorted view that Cowper, highly influenced by 18 th century obsolete historians such as Robertson, offers us of Hernán Cortés; this is regardless of the extensive renovations carried out by some authors of the 1st half of the 19th century in their documented studies, known by Usoz, such as George Ticknor, Martín Fernández de Navarrete or Washington Irving.

In letter $n^{2} V$ (Madrid, 27th January 1844) Usoz echoes the turmoils that took place during and after the fall of Espartero's Regency and, immediately after, he highlights the foreigners' atraction towards Spain and the Spanish, especially during the last century. To this end, he recounts G.P. Borrow's singular ideas about the matter and the very amusing absurdities collected in his book The Bible in Spain. It is a book full of inventiveness, in which the Spanish both collectively and individually are regarded as a gang of fanatical, ignorant and brutal outlaws and smugglers, a focus of syphilis, and slaves to friars. Likewise, Usoz is not to be outdone in his letter, where he refers to “... la ferocidad de los aragoneses, el carácter frívolo de los valencianos, la guitarra de los andaluces, y la afición de todos los españoles a las corridas de toros...".

In letter no. VI (Santiago, 19th July 1850) Usoz announces his imminent visit to the United Kingdom, postponed for a long time, and to which we have referred at length above; whereas in no. VII (Santiago, 25th September 1850) he describes his return to England in pages full of vivacity and colour, especially mentioning the eventful journey from Southampton to Vigo, namely the rough ocean and the passengers' stormy and unavoidable controversies about slavery.

There is also a splendid description of the vicissitudes lived by Usoz and his young fellow traveller on the road to Santiago. Both rode mules, loaded with books and presents bought in England; and they were told stories about audacious English propagandists who, 
escaping the clergy, mayors and Civil Guards' vigilance, managed to distribute "Protestant" copies of the New Testament in the heart of Galicia and León mountains. These stories reminded the young professor of Borrow's adventures which had happened fifteen years before, and those of his assistant, a Toledan rustic peasant, who, with the enthusiasm peculiar to the convert, used to go over the Castilian villages on horse back with the saddlebags filled with forbidden books announcing his goods with shouts of "¡viva Inglaterra! ¡viva el Evangelio!." With such irrelevant conversations, gentleman and servant arrived at Santiago de Compostela on 14th September 1850, which was then a sad and always misty city of 5,000 urban residents (around 25,000 inhabitants), with a reputable University, a large student population, bad lodgings and a monastic flavour.

\section{A philological analysis of the text presented}

It has been underlined in the above short comment on the content of the letters how nos. III and IV (and to a less extent nos. I, II and V) touch upon purely philological issues, more particularly upon those practical problems posed by Santiago Usoz both learning the English language and in his work as a translator. As regards the learning process, due to the above mentioned absence of the native speaker who initiated him into it, Usoz became an autodidact attached to a grammatical rather than conversational methodology, and therefore exclusively theoretical and separate from the communicative reality. With such limitations he found it very difficult to immerse himself into the English language. Only the desire to read his favourite English writers, especially the poet William Cowper, would lead him to continue in his enormous and not very gratifying endeavour.

Letter no. I describes problems of translation, those relating to a certain Spanish version of an antislavery treatise by Sir Frederic Madden, a well-known British abolitionist. His co-religionists, George W. Alexander and B. Wiffen, intended to distribute it in Spain to obtain the supression of the black slave trade in the Spanish Antilles. This first Spanish version, brought by Wiffen and Alexander on a visit to our country, struck Usoz as unprintable because it was excessively literal, that is, it reproduced the offensive tone of the original text in relation to Spain and the Spanish. Therefore, he offered himself either to revise it or to do a new translation more suitable for Hispanic readers. Above all, Usoz considered the review or re-working of the mentioned text to be a means of social awakening in relation to the struggle against slavery. That is why, without pursuing any didactic aim to consolidate the learning of rules and linguistic structures of $\mathrm{L2}$, the author was interested in the functional role of communicating, transmitting, reporting and persuading with regard to certain contents, both to the Spanish parliament and to society in general.

With this aim in mind, Usoz needed some acceptable knowledge of both linguistic codes in order to solve problems such as the reading comprehension of the original text (L1), its comparison with the translation (L2), and detection of the defects of the latter in order either to correct it or to translate it again. The fact that he probably lacked such knowledge leads us to question his capacity for carrying out his task as a reviser (much less as translator). Moreover, the final achievement of the communicative purpose in L2 
(the final text) would imply the need of betraying the ideas gathered in L1 (the original). Therefore, Santiago Usoz's project could only mean a real challenge, given the constrictions due not only to his own technical limitations, that is, his rudimentary knowledge of the English language, but also to extremely adverse extraphilological circumstances. In fact, what attracts our attention to a great extent is the high amount of motivation the author reflects in his letter (“... me ofrezco de nuevo a hacer todo lo que esté en mi mano para llevar a cabo el objeto de nuestra reducidísima sociedad"). ${ }^{10}$ This motivation makes him forget the real difficulties inherent in his mentioned task, in order to immerse himself in purely extralinguistic aims.

In letter $\mathrm{n}^{\mathbf{2}}$ II, Santiago Usoz pays attention to matters of translation. He disapproves of George Borrow's omission of the non-canonical books, for religious reasons, in his reedition in Madrid of the translation of the Bible by Felipe Scío de San Miguel. In fact, such books are regarded as apocryphal amongst the Protestant and the Jewish. However, it is as well to bear in mind that Usoz's disapproval is not due to philological considerations (the mutilation of Scio's original), though occasionally he may imply the opposite. His purpose is as extraphilological (the spreading of the reformed Christianity amongst the Spanish) as Borrow's. Thus, whereas this latter eliminates any book that stands for the Catholic dogmas and traditions, Usoz deems such a decision as incorrect, given that it betrayed him as a Protestant with the subsequent potential reader's rejection: "... y esto hace que muchos no la quieran comprar."11

In addition to Borrow's religious motivation, also shared by Usoz himself, we find a purely commercial one. This is not an obstacle to the latter's formulation of a second criticism; criticism supposedly philological and also religious about the variations detected in Borrow's text in relation to the English Protestant Bible he owned: “... yo la he cotejado con una que tengo en inglés, $y$ en algunos versículos difiere." ${ }^{\prime 2}$ This fact, on the one hand, suggests that Usoz compared the reference work with the original text and, on the other hand, it gives us further information about the didactic material used for learning the English language. It is obvious that, in addition to William Cowper's work, he also possessed some other English books, including an English Bible.

Letter no. III focuses on those practical problems posed by Usoz during the absence of the native speaker who had initiated him into L2. This time he was forced to learn alone with no other explicit help than the reading of Cowper's poems. As has been mentioned above, he owed his linguistic intuitions both to this command of classical languages and to his natural inclination to the critical analysis of certain practical problems as those referring to the limitations in reading comprehension and pronunciation. Likewise, all these intuitions would result in common sense remarks of certain philological interest. For instance, remarks that have to do with the difficulty of memorizing the meaning of each word, especially in the case of monosyllables and two-syllable words that just differ in one or two letters, or with the polysemic usage of words with the same or similar sound.

There can be no doubt that Usoz's above-mentioned command of Greek and Latin made much easier his understanding of the theoretical texts used for learning the English language. In fact, the most usual techniques attached to the learning of modern languages were those ones used in the classics. Mariano Cubí y Soler, an established authority, stated the following in El traductor Español: “... a knowledge of the ancient languages, is 
indispensably necessary". That is, Latin and Greek had attained such prestige since the Renaissance that, in spite of the 17th century growing process of substitution of other modern languages (French and later English) for the two former ones, the methodology used to learn them not only was regarded as a fundamental model but also influenced the didactic aspects of living languages until well into the 19th century.

Usoz never mentions having used any grammar, vocabulary list or dictionary, though undoubtedly he must have had easy access to them. Otherwise, both Sofía MartínGamero's and Aquilino Sánchez Pérez's works guide us through the didactic materials used for learning English in the Spain of the period. This latter author, though focusing his research on the learning of the Spanish language abroad, brings forward and studies an important, dense and interesting compendium of works relating both to English and Spanish (Sánchez Pérez 481-490), namely: “Anglo-Spanish Grammars” published in Spain as were those by Francisco G. Feraud (1821) or Manuel Ainsa Royo (1837) "para uso de españoles", vocabularies, Spanish-English and English-Spanish dictionaries and conversational methods, published abroad though circulated in our country.

It should be born in mind, as J. Girald del Pino said some years ago, that, learning a modern language, no matter how good a Latinist or Hellenist one may be, implies the subjection to the rules prescribed by its grammar, in this case English grammar. In view of the fact that this subjection is not enough to immerse oneself entirely into the language acquired, even the most faithful followers of the Traditional or Grammatical Method, open to positive innovations, looked for new and more realistic techniques. Thus, Cubí y Soler used to call them pompously the "new and practical system" and Emmanuel del Mar entitled one of his most well-known works as $A$ theoretical and practical Grammar (22). At any case, Cubí (A New Spanish Grammar V) observes that "... the final success of the student will and most absolutely depend on his application, knowledge (...) particular talents, or appropiate age (...) who, by study and reflection, has acquired experience, quickened his penetration, and matured his judgment."

Judging by Usoz's statement (“... no sé pronunciar ni bien ni mal..."), it seems that the author's preoccupation was particularly centred on the acquisition of a correct pronunciation. Such phonetic limitations were not only difficult to overcome, given the great disparity within the English language between spelling (much closer to the old diction than to the new one) and pronunciation but also aggraviated by the absolute lack of command of lexical and syntactic aspects; "... para entender seis versos necesito media hora." Nevertheless, even though Usoz had some theoretical knowledge, to know the grammar of L2 is not equivalent to have a good command of it. With regard to this, in 1833 Emmanuel del Mar (XI) referred to the "Necessity of oral instruction [and] not only written precepts." This was far from being a new reflection, since two decades before George Ticknor was aware of the fact that "... el mejor método y el más fácil [en el estudio de un idioma extranjero]... es el que permite aprenderlo como lengua hablada" (Sánchez Pérez 308).

Usoz's phonetic limitations are almost pathetic, because he was not content with reaching a certain level of reading comprehension as in the case of Benjamin Franklin (“... con un poco de esfuerzo y sacrificio aprendí el español necesario para leer también libros en esta lengua" [Sánchez Pérez 302]). Just as J. Russell Lowell would say, going further, 
Usoz regarded the full possession of the L2 as a "... medio o instrumento para llegar a la literatura." (Sánchez Pérez 310) That is why his main goal was reading Cowper in the original language. As a matter of fact, it is difficult to reach full enjoyment of literary beauty if beforehand one does not have a good grasp of phonetics. Not in vain, language, apart from being a written code, has also an oral side, through which Usoz would have gained access to the musicality (that is, rhythmical and prosodic aspects) of the English language.

Such reflections are gathered in letter no. IV, which, to a certain extent, is a continuation of the previous one. Once more, he regrets not being able to get greater benefit from his reading because of his poor command of the English language. "Quisiera que algunas de sus poesías - he writes referring to Cowper- deleitasen mi oído como deleitan mi alma, pero... me falta la pronunciación." On the contrary, in letters nos. $\mathrm{V}$ and VII there is no mention of linguistic matters, whereas no. VI announces Usoz's imminent short visit to England during the Summer of 1850. At that time, in which the audio-oral methods (as they are understood nowadays) did not yet exist, travelling to a foreign country was the only way of immersing oneself into its language.

\section{Conclusions}

According to the above philological study, only letters nos. I, II, III and IV touch upon Usoz's practical problems both learning the English language and in his work as translator. His learning techniques, influenced by the previous acquisition of Latin and Greek, are attached to the Traditional or Grammatical Method and therefore exclusively normative and separate from the communicative reality.

Given Usoz's tendency to the peculiar and critical reflections together with his co.iunand of the classical languages, the above-mentioned limitations are not an obstacle to the author's vague though correct philological intuitions. Namely: the correspondence between the phonic side of words and its corresponding meaning and the polysemic use in the English language. And on the other hand, it should be emphasized Usoz's facet as translator. That is, his great amount of motivation (though more religious than philological), his attentive comparison of sources and the total subjection to the achievement of the communicative purporse in the translation (L1) by means of betraying the ideas of the original (L2).

\section{Notes}

1. See Vilar, Mar. "La lengua y civilización inglesas en sus relaciones con España a mediados del siglo XIX. Siete cartas de Santiago Usoz y Río al hispanista Benjamín B. Wiffen ( 1841 1850)." Boletin de la Real Academia de la Historia. (1995). Forthcoming.

2. Vilar, Juan Bta.. Intolerancia y libertad en la España contemporánea. Prólogo de R. Carr. Madrid: Ed. Istmo, 1994.

3. Wiffen, Jeremiah H. The Works of Garcilaso de la Vega. London: 1823.

4. Wiffen, J.H.. Jerusalem liberated. London: $1824-1825,2$ vols. 
5. AWCO, ScWp, Letters of L. Usoz and B.B. Wiffen.

6. La Biblia o el Antiguo y Nuevo Testamento, traducidos al español de la Vulgata Latina, por el Rmo. P. Phelipe Scío de San Miguel, de las Escuelas Pías, Obispo de Segovia. Barcelona: 1837.

7. See Benveniste, Emile. Problèmes de Lingüistique Générale (1966); Heger, Klaus. Monen, Wort, Satz und Text (1976); Lakoff, G. Women. Fire and dangerous Things (1987).

8. Cowper, William. Works. Edited by Robert Southey. London: 1835-1837, 15 vols.; Cowper. The letters and Prose Writings. Edit. James King \& Charles Ryskamp. London: 1978-1980, 2 ts.

9. AWCO, ScWp. S. Usoz to B.B. Wiffen, Madrid 27-I-1844.

10. Ibídem, Usoz to Wiffen, Madrid 9-I-1841.

11. Ibídem, Usoz to Wiffen, Madrid, (?), III-1843.

\section{ABBREVIATIONS}

AWCO: Wadham College Archives (Oxford)

ScWp: Spanish Collection, Wiffen Papers

\section{Works cited}

Borrow, George P. The Bible in Spain. London: 1842.

Boehmer, Edward. Biblioteca Wiffeniana. Spanish Reformers to two centuries from 1520. Strasbourg-London: Ed. Trübner, 1874-1902, 3 vols.

Cubí y Soler, Mariano. El traductor Español; or, a new and practical system for translating the Spanish Language. Printed for Boosey \& Sons. London: Broad st., Royal Exchange, 1826. . A New Spanish Grammar, adapted to every class of learners. By (...). London:

Printed for Boosey \& Sons, 1826.

Giral del Pino, Joseph. A New Spanish Grammar; or, the Elements of the Spanish Language: containing an easy and compendious method to speak and write it correctly: with several useful remarks on the most particular Idioms, and Fundamental Rules, showing how to make use fo them, both in Speaking and Writing. The whole extracted from the best observations of Spanish Grammarians, and particularly of the Royal Spanish Academy of Madrid. To which is added An English Grammar, for the use of Spaniards. Printed for F. Wingrave. London: 1800 , s.p.

Mar, Emmanuel del. A Theoretical and Practical Grammar of the Spanish Language, adapted to all classes of learners: in thirty lectures, with exercises and key. First London Edition. By (...), author of "A Treatise on English Pronunciation for the Use of Spaniards." London: J. Wacey, succesor to T. and T. Boosey, and Ackermann and Co., 1833.

Martín Gamero, Sofía. La enseñanza del inglés en España. Madrid: Ed. Gredos, 1961.

Pattinson, Samuel R.. The brothers Wiffen: memoirs and miscellanies. Hodder and Stoughton. London: 1880, 1-62, 79-142.

Sánchez Pérez, Aquilino. Historia de la enseñanza del español como lengua extranjera. Madrid: Sociedad General Española de Librería, 1992. 